\title{
Feasibility of Implementation of Public Entity Corporate Governance Act's Best Practices to Enhance Good Performance in a State-Owned Enterprise
}

\author{
Adegbola Otekunrin ${ }^{1, *}$, Kudzanai Matowanyika ${ }^{2}$, Clever Fungai Munyoro ${ }^{3}$, Ngoni Doma ${ }^{3}$, \\ Stella Ibitoye ${ }^{1}$ \\ ${ }^{1}$ Department of Accounting \& Finance, Landmark University, Nigeria \\ ${ }^{2}$ Graduate Business School, Chinhoyi University of Technology, Chinhoyi, Zimbabwe \\ ${ }^{3}$ Department of Accounting Sciences and Finance, University of Technology, Chinhoyi, Zimbabwe
}

Received January 16, 2020; Revised January 16, 2021; Accepted January 28, 2021

\begin{abstract}
Cite This Paper in the following Citation Styles
(a): [1] Adegbola Otekunrin, Kudzanai Matowanyika, Clever Fungai Munyoro, Ngoni Doma, Stella Ibitoye, "Feasibility of Implementation of Public Entity Corporate Governance Act's Best Practices to Enhance Good Performance in a State-Owned Enterprise," Universal Journal of Accounting and Finance, Vol. 10, No. 1, pp. 1-9, 2022. DOI: 10.13189/ujaf.2022.100101.
\end{abstract}

(b): Adegbola Otekunrin, Kudzanai Matowanyika, Clever Fungai Munyoro, Ngoni Doma, Stella Ibitoye (2022). Feasibility of Implementation of Public Entity Corporate Governance Act's Best Practices to Enhance Good Performance in a State-Owned Enterprise. Universal Journal of Accounting and Finance, 10(1), 1-9. DOI: 10.13189/ujaf.2022.100101.

Copyright $\odot 2022$ by authors, all rights reserved. Authors agree that this article remains permanently open access under the terms of the Creative Commons Attribution License 4.0 International License

\begin{abstract}
This study examined the feasibility of implementing the Public Entity Corporate Governance Act's (PECGA) best practices to enhance good performance at a State Owned Entity (SOE). Boards of State enterprises and parastatals (SEPs) had encountered impediments in promoting corporate governance best practices in Africa. Identified factors hindering the implementation of PECGA of 2018 were examined to proffer recommendation for its adoption. Zimbabwe came up with the PECGA of 2018. The feasibility of implementing PECGA's best practices to enhance good performance at the SOE is not well known when this study was conducted. Mixture research methods were adopted where questionnaires were used to collect data. Purposive sampling methods were used to examine the populations of 38 head office managerial staff. Chi-square and regression analysis were used for analysis. It is found that job title and education level are related and the execution of sound PECGA best practices and the SOE's operational performance are related. The results confirmed that there were hindrances on the execution of sound PECGA best practices on the SOE's operational performance. The study concluded that it is not feasible to fully implement the
\end{abstract}

PECGA best practices in SEPs to enhance performance in Zimbabwe. The Zimbabwean's PECGA must be moved from the "apply or explain" model (that is relying on the disclosures requirement doctrine as a method of promoting the execution of definite corporate governance practices devoid of mandating real practices) to "comply or else" model of corporate governance to achieve sustainable corporate governance success in the near future.

Keywords Governance, Implementation, Public, Entity

\section{Introduction}

Corporate governance (CG) failures are very topical these days in both the private and public sector [49]. There is a massive drive towards the ever-rising need for accountability and transparency, coupled with the need for having checks and balances in any company. On the Global stage, Moyo [35] mentions that corporate scandals which consisted of big companies such as Enron, WorldCom, 
Tyco, and Parmalat have called for new height in corporate governance management. Nationally in Zimbabwe, we have seen leading companies violating corporate governance principles over the years and of significant concern are the State Enterprises and Parastatals (SEPs). The country has had its fair share of scandals and corporate failures, such as African Renaissance (AFRE), Zimbabwe Broadcasting Corporation, Public Service Medical Aid and Zimbabwe Iron and Steel Company (ZISCO), [50]. The most topical was the PSMAS saga, where the CEO earned an "outrageous" salary and allowanced up to US\$500 000 per month, shockingly this was done with the approval of the board which was not conscious of the effects as the company was failing to honour debts owed for services rendered to its members [35].

State enterprises and parastatals (SEPs) have performed poorly, as was stated in the World Bank economic update report 2016. This report asserts that commercially SEPs since 2011, has recorded collective loss under US $\$ 340$ million. According to [60], the significant reasons state-owned enterprises and parastatals are failing are poor administration of resources by the board of directors, fraud, corruption, and excessive remunerations for the board of directors. The Zimbabwe national budget statement of 2018 under point 176, p48 published that parastatals contribution to the state's gross domestic product had dropped drastically from $60 \%$ to $2 \%$. However, it was recorded that against that backdrop of parastatals losses, management spoiled themselves with huge salaries and perks, in non-cooperation of Cabinet's directive, which stated that management's benefits must not surpass $30 \%$ of the total revenue.

Zimbabwe's government came up with the Public Entity Corporate Governance Act of 2018 (PECGA) to mitigate these challenges. Enthusiasts of corporate governance pose countless opinions in advocating for adoption and approval of such codes and acts for the advantage of stakeholders, shareholders and investors. The separation of ownership and control was cited as a major concern area (agency theory). The ideal scenario is that State should be separate from the State-owned enterprises (SOEs) as a body corporate; hence, the board of directors must be given space and left to run the enterprises independent of any State influence and interference. The researchers are then prompted to carry out a study on the feasibility of implementing Public Entity Corporate Governance Act best practices to enhance good performance at an SOE. Maune [33] alludes that in African developing countries, the boards of SEPs have encountered impediments in their efforts to promote $\mathrm{CG}$ best practices.

The selected SOE for this study is no exception as it is facing serious challenges which are; overstayed board most of them unchanged since 2007 to date despite numerous advice by the Corporate Secretary to the sitting Minister on Board terms expiry, no movements were effected, low productivity, insurmountable political interferences, bureaucratic reporting, poor service delivery leading to stakeholder dissatisfaction, failure to retain a highly motivated and skilled workforce as well as failure to turn itself into a profit-making entity and no sufficient attention has been focused to the hindrances being met by boards of SEPs in executing their jobs to enhance best practices in corporate governance [56].

\section{Literature Review}

\subsection{The Concept of Corporate Governance (CG)}

Many scholars have given CG various definitions. Shaji [48:10] stated that: "Corporate governance is the set of processes, customs, policies, laws and institutions affecting the way a corporation is directed, administered or controlled". In the same way, the citing European Central Bank [19], OECD [38:151] states that it is "procedures and processes according to which an organisation is directed and controlled. The CG structure specifies the distribution of rights and responsibilities among the different participants in the organisation - such as the board, managers, shareholders and other stakeholders - and lays down the rules and procedures for decision-making." According to [48:10], "in a narrow sense, CG involves a set of relationships amongst the company's management, its board of directors, its shareholders, and other stakeholders. These relationships, which involve various rules and incentives, provide the structure through which the objectives of the company are set, and the means of attaining these objectives as well as monitoring performance are determined", but [48:11] asserts that: "in a broader sense, CG involves - the extents to which companies are run openly and honestly. It is important for overall market confidence, the efficiency of capital allocation, the growth and development of countries' industrial bases, and ultimately the nations' overall wealth and the welfare of the society." Hence [48:13] concluded that: "it is a set of systems and processes to ensure that a company is managed to suit the best interests of all." It means for the interest of every the stakeholder in any capacity.

\subsubsection{Effect of Corporate Governance on Firm Economic Performance}

Mwangi [36:37] assert that "good CG has a positive economic impact on an organisation as it saves the organisation from various losses, e.g. those occasioned by frauds, corruption and similar irregularities." This view is supported by [5], [58] and [4]. Adams and Mehran [1] agree that poor CG in organisations paves the way for corruption alliances among politicians and state enterprises. McKinsey \& Company [34] performed a survey in Malaysia, and the results were that investors were more inclined to offer a premium to organisations with good CG. 


\subsection{Zimbabwe Context and Regulation}

\subsubsection{Sources of Corporate Governance Practices in Zimbabwe}

According to [35:5] "Zimbabwe's CG framework for public entities is compared to South Africa and Australia's frameworks. South Africa and Australia were chosen because of the similarities they share with Zimbabwe. For example, all three countries' company laws have historically borrowed heavily from the United Kingdom's company law. Their CG systems consist of both mandatory and self-regulating attributes" Hence, Zimbabwean CG leans on the Companies Act Chapter 24:03, South African Code (King 1, 2 and 3), the historic and iconic Cadbury Code and its successors, for instance, the UK Combined Code on CG [11], [16], [52], [53] and [54]. Zimbabwe' 2010 CG framework for state enterprises as well as parastatals as well comes into play [17]. This Code was established to act as a guide and a means of assisting the state enterprises. In this thrust, Zimbabwe National Code on CG (ZIMCODE), was also published by, The Institute of Directors Zimbabwe in April 2015. This was followed by the PECGA [43], which culminated into the PECGA [42].

\subsubsection{Zimbabwe National Code on Corporate Governance}

The is Code was modelled around the "apply or explain" way, implying that organisations must adapt to the principles it spells out and that they are obliged to reveal the reasons for failure to comply with the principles to execute sound CG best practices which both the private and public entities can institutionalise [60]. The ZIMCODE chapter on ownership and control advocates and promotes the rights of several classes of shareholders. The Code also addresses the board of directors' sighting that they should have unquestionable attributes, to carry out their tasks diligently [12].

\subsubsection{Public Entities Corporate Governance Act (PECGA)}

Zimbabwe's government came up with the PECGA [42] to the issues of CG in SOEs. Zimbabwe's CG approach is the "apply or explain" basis, which entails that the principles outlined are to be complied with but not obligatory. The organisation will have to prove adequate explanations for non-complying (PECGA Chapter 7, Compliance and Enforcement Section 371). The Act has sections on the following matters; "CG unit, appointment, tenure and conditions of service of the boards of public entities, strategic plans and performance contracts, board charters, codes of ethics and national code of CG and conduct of business by boards of public entities." Sections 11(2) p82 states that: "no person shall be appointed as a member of the board of a public entity for a term longer than four years, and the appointment may be renewed for only one further such term." The issue of knowledge was added in which under section 11(6) p83 members are now required to be "appointed for their knowledge of or experience in administration, the management or any other field that is relevant to the operation and management of the public entities concerned."

\subsubsection{Problems Hindering the Effective execution of Corporate Governance Best Practices in SEPs}

It is difficult to talk about CG challenges without touching on business ethics and stakeholder management. Chipunza [14] and [27] attests that corruption and nepotism were rampant in African countries. Solomon [51] felt that nepotism was also rife, and it entails the practice of hiring relatives without following the laid down recruitment process in an organisation or favouritism based on kinship. Gberevbie, Oyeyemi and Oluye [20:1] cited [22], [6] as well as [57] and argued that "good governance in any nation is the relative absence of corrupt practices in all its ramifications. This position implies that in a nation where corruption has almost become the norm, such a nation cannot claim to experience good governance." Moyo [35:333] stated that "the relevant authorities have not exhibited much political will to eliminate corruption as they have mostly concentrated on the symptoms and not root causes of corruption. As a result, the government needs to establish ways of eliminating corruption, create an adequate legal and judicial framework and be committed and more consistent in the implementation of good CG standards and enforcement of compliance."

Moyo [35:331] also stated that "the legal and regulatory framework governing the appointment of board members has loopholes that have adversely impacted on the effectiveness of boards. Board members are appointed for the wrong reasons and therefore lack the necessary skills and expertise to direct the respective entities towards achieving their goals effectively." By implication, PECGA has loopholes in terms of appointment of board members. According to Moyo [35:331] "the irregular appointment of directors, achieving board diversity appears not to be always possible in Zimbabwe, especially concerning relevant expertise and gender. In some cases, the people appointed as directors are usually not well-versed with the complexities of the public entity and the industry in which it operates and the applicable laws and regulations. The absence of expertise and relevant skills makes it difficult for public entity boards to effectively discharge their duties. Also, gender equality has not been given the prominence it deserves in the selection and appointment of board members." Moyo [35:332] assert that "given the fact that the responsible authorities are not regularly monitoring and evaluating the boards' performance, the boards may not have the motivation to effectively discharge their mandate especially if they believe that the shareholders are not interested in the outcome of their actions be it failures or achievements.." Hence, there need to monitor them to ensure sustainable results are accomplished continually. 


\subsubsection{Hypothesis Formulation}

The research study statement of the problem had observed that the SEPs had encountered impediments in their efforts to promote CG best practices in African developing countries. To mitigate these challenges, the government of Zimbabwe came up with the PECGA. This Act was long overdue and is most welcome; however, it is coming into an environment that has been greased into corruption, fatty pocket mentality (the famous salary gate scandal), uncontrolled political interference, nepotism on board member selection were political alignment to the ruling party is an advantage. It expected several internal, external factors and "political driven forces" just mentioned above may constitute hindrances to the effective execution of PECGA. Hence, this study examined if these factors are hindrances. To specifically address the issue of nepotism on board member selection, this study examined if a job title and level of education are related in the selected SOE. The study also assessed the feasibility of implementing PECGA Best Practices to hence good performance at the SOE because the Act follows the "apply or explain" model of CG. This implies that actual practices are not mandatory, but it uses the principles of the disclosures to encourage the implementation of definite CG. For this reason, this study examined if the execution of sound corporate governance PECGA best practices and the SOE's operational performance are related. Hence null hypotheses stated below were tested:

$\mathrm{H}_{1}$ : Job title and level of education in the SOE are not significantly related

$\mathrm{H}_{2}$ : Execution of sound corporate governance PECGA best practices and the SOE's operational performance are not significantly related

$\mathrm{H}_{3}$ : There are no hindrances on the effective execution of sound corporate governance PECGA best practices on the SOE's operational performance

\subsection{Theoretical Framework of Corporate Governance}

\subsubsection{Agency Theory}

Agency theory is about the separation of ownership of the Company from its management as managers are agents while shareholders are principals [25]; [18]; [9]. Iturriaga and Rodriguez [24] attest that the agency- principal relationship results if not managed well may result in the agency problem. Agency problem refers to the conflict of interest between the agent (management) and the principal (owner/shareholder). An agent (Director/Manager) as a rational human being, would take decisions that would maximise their self-interest at the expense of the principal (owner/shareholder) interest and firm' value [29], [41], [39], [40]. The issue of separation of ownership and control was cited as a major concern area in the feasibility of implementation of Public Entity Corporate Governance Act best practices to enhance good performance at an SOE [33]. This is the reason, agency theory is adopted.

\subsubsection{Stewardship Theory}

This theory attests that stewards (firm's executives) and combining with management work for shareholders' benefit [58]. Isingoma, Abuda, Wainana and Mwangi [28] states that stewardship theory is made on the belief that managers, left alone, will act for the benefits of their masters thus protect and maximise shareholder's wealth through firm performance. The stewards are viewed as the company executives and managers. It posits that they seek to protect and guard the interests of shareholders jealously and guarantee returns. Ghulam, Binish, Zeeshan, and Alia [21] expand that the stewardship theory assumes that senior management forgoes their personal lives for the organisation and its future success. The government owns SOEs; hence, SOEs' board of directors is expected to be good stewards to the government in running the SOEs. This is the reason, stewardship theory is adopted.

\subsubsection{Stakeholder Theory}

The stakeholder theory was put forward by [32]; it postulates that managers in companies have various stakeholders to serve, which entails shareholders, business partners, employees, and suppliers. Hence, the theory affirms that an organisation's stakeholders include everyone affected by its operations. According to [55] and [45], the Stakeholder theory defies agency assumptions on the importance of shareholder interest. Instead, it posits that a firm should be administered in the interests of every stakeholder. Shahzad, Rutherford, and Shartman [47] highlighted that the theory emphasises managerial decision crafting and that every stakeholder's interest has a core value, and no group of interests is believed to control the others. This depicts the corporate environment as a set of related groups, in totality requiring consideration and gratifying with the company's achievement going concerned [8]. Hence, it avows that a firm needs to be governed in a style that addresses all stakeholders' interests [44]. Zimbabwe adopted PECGA for the benefit of all stakeholders. This is the reason, stewardship theory is adopted.

\section{Methodology}

In this study, the researcher adopted a mixture of positivism (quantitative) and a bit of phenomenology (qualitative) methods because it is a study of social phenomena in line with [10]. A descriptive research design was employed to obtain the opinions of persons in the target population concerning the feasibility of implementing Public Entity Corporate Governance Act best practices to enhance good performance at the $\mathrm{SOE}$ in line with [46]. The researcher used the case study of the SOE Board in line with [7]. Questionnaires approach and face to face interviews were used to collect data from the board members and selected management employees of the SOE Board. This was also aided by the researcher's 
assessment of the various responses given by the target population. The researcher elected to take a quantitative analysis using closed-ended questionnaires with response options under the Likert scale in line with [14]. The selected sample for this study was the entire SOE head office management. The table below shows the composition of the targeted population, Sample and Sample Size.

Table 1. Sample Selection

\begin{tabular}{|c|c|c|c|}
\hline Targeted Participants' Category & $\begin{array}{c}\text { Total Number of Participants } \\
\text { Targeted (Population) }\end{array}$ & Sample & Sample Size \\
\hline Non-Executive Directors & 9 & 9 & $100 \%$ \\
\hline Executive Directors & 5 & 5 & $100 \%$ \\
\hline Senior Managers & 5 & 5 & $100 \%$ \\
\hline Middle Management & 10 & 10 & $100 \%$ \\
\hline Accountants & 2 & 2 & $100 \%$ \\
\hline Auditors & 8 & 8 & $100 \%$ \\
\hline Total & $\mathbf{3 9}$ & $\mathbf{3 9}$ & $\mathbf{1 0 0 \%}$ \\
\hline
\end{tabular}

\section{Result and Discussion}

\subsection{Hypothesis Testing}

A hypothesis testing was carried out to determine whether job title and education level in the SOE are related.

Hypothesis 1:

$\mathrm{H}_{1}$ : Job title and level of education in the SOE are not significantly related

Table 2. Chi-Square Test for Association of the level of education and job title

\begin{tabular}{|c|c|c|c|}
\hline & Value & df & Asymp. Sig. (2-sided) \\
\hline Pearson Chi-Square & $19.843^{\mathrm{a}}$ & & .031 \\
Likelihood Ratio & 22.955 & 10 & .011 \\
Linear-by-Linear Association & 8.509 & 10 & .004 \\
N of Valid Cases & 39 & 1 & \\
\hline
\end{tabular}

In Table 2 above, the test for association between respondents' job title and level of education, at $95 \%$ confidence interval, (chi-square $=19.843, \mathrm{p}=.031$ ) revealed that the level of significance is less than 0.05 .

Decision: Reject $\mathrm{H}_{1}$ and conclude that job title and level of education in the SOE are significantly related. This result reveals that the employee's job title is significantly associated with the level of education. The relationship is not by chance. Hence, the level of education increases with the level of one's job title. This entails that the Company is rewarding employees for personal development and argued before a knowledgeable workforce is required to enhance corporate governance implementation. This is in agreement with [14], [51], [44], [26] as well as [3]

\section{Hypothesis 2:}

\section{$\mathrm{H}_{2}$ : Execution of sound corporate governance PECGA best practices and the SOE's operational performance are} not significantly related

Tested using linear regression models specified as

$$
Y=\alpha+\beta X_{i}+\varepsilon
$$

Where $\mathrm{Y}$ is the Dependent Variable which is Improved Financial Performance

$\alpha$ Is the Intercept

$\beta$ is the Coefficients of Xs

$X_{i}$ is the dependent variables being; conflict of interest, political appointees, strategic planning, political interference, remuneration caps on senior staff, lack of integrity and ethics.

$\varepsilon$ is the error term

Table 3. Synopsis of Linear Regression model

\begin{tabular}{|c|c|c|c|c|c|c|c|c|c|c|}
\hline \multirow{2}{*}{ Model } & \multirow{2}{*}{$\mathrm{R}$} & \multirow{2}{*}{ R Square } & \multirow{2}{*}{$\begin{array}{c}\text { Adjusted R } \\
\text { Square }\end{array}$} & \multirow{2}{*}{$\begin{array}{c}\text { Std. Error of the } \\
\text { Estimate }\end{array}$} & \multicolumn{4}{|c|}{ Change Statistics } & Durbin-Watson \\
\cline { 7 - 12 } & & & & R Square Change & F Change & df1 & df2 & Sig. F Change & \\
\hline 1 & $.655^{\mathrm{a}}$ & .429 & .322 & .642 & .429 & 4.002 & 6 & 32 & .004 & 2.434 \\
\hline
\end{tabular}

a. Predictors: (Constant), Conflict of Interest, Political Appointees, Strategic Planning, Political Interference, Remuneration Caps on Senior Staff, Lack of Integrity and Ethics

b. Dependent Variable: Improved Financial Performance 
According to Table 3, the Calculated results show an $\mathrm{R}^{2}$ of $43 \%$. A low $\mathrm{R}$ Square may be explained by the other factors not captured in the model and study like the agriculture sector's performance, political sanctions that the country is under, the effectiveness of the parliamentary supervision and the general economic environment Zimbabwe which has been volatile.

Table 4. Linear Regression Model Results

\begin{tabular}{|l|c|c|c|c|c|}
\hline \multirow{2}{*}{ Model } & \multicolumn{2}{|c|}{ Unstandardised Coefficients } & \multicolumn{2}{c|}{$\begin{array}{c}\text { Standardised } \\
\text { Coefficients }\end{array}$} & \multirow{2}{*}{ Sig. } \\
\cline { 2 - 6 } & $\mathrm{B}$ & Std. Error & Beta & & \\
\hline (Constant) & 4.744 & 2.019 & & 2.350 & .025 \\
\hline Lack of Integrity and Ethics & -.366 & .167 & -.669 & -2.187 & .036 \\
\hline Political Appointees & .050 & .177 & .045 & .282 & .780 \\
\hline Political Interference & .191 & .261 & .125 & .732 & .470 \\
\hline Strategic Planning & .199 & .161 & .211 & 1.240 & .224 \\
\hline Remuneration Caps on Senior Staff & -.486 & .156 & -.720 & -3.118 & .004 \\
\hline Conflict of Interest & .410 & .169 & .638 & 2.422 & .021 \\
\hline
\end{tabular}

a. Dependent Variable: Improved Financial Performance

The regression analysis results Table 4 above shows that the following variables were found to be statistically significant; $(\beta=-0.366 ; p$-value $=.036<0.05)$ for lack of integrity and ethics, $(\beta=-0.486$; $p$-value $=.004<0.05)$ remuneration caps on senior staff and $(\beta=0.410 ; p$-value $=.021<0.05)$ conflict of interest. Except for conflict of interest, the other two variables had the correct size of Beta.

Decision: Reject $\mathrm{H}_{2}$ since there is a statistically significant variance that shows that sound corporate governance as a measure by improved financial performance is a function of the operational performance. This confirms that the execution of sound corporate governance PECGA best practices and the SOE's operational performance are significantly related. Maranga [28], Alabede [14], Ueng [58], Moyo [35], Adegbie and Fofah [2] concurs with the result

\section{Hypothesis 3:}

$\mathrm{H}_{3}$ : There are no hindrances on the effective execution of sound corporate governance PECGA best practices on the SOE's operational performance

Table 5. Cross-tabulation of the SOE Profitability in the last5 Years and Strategic Planning

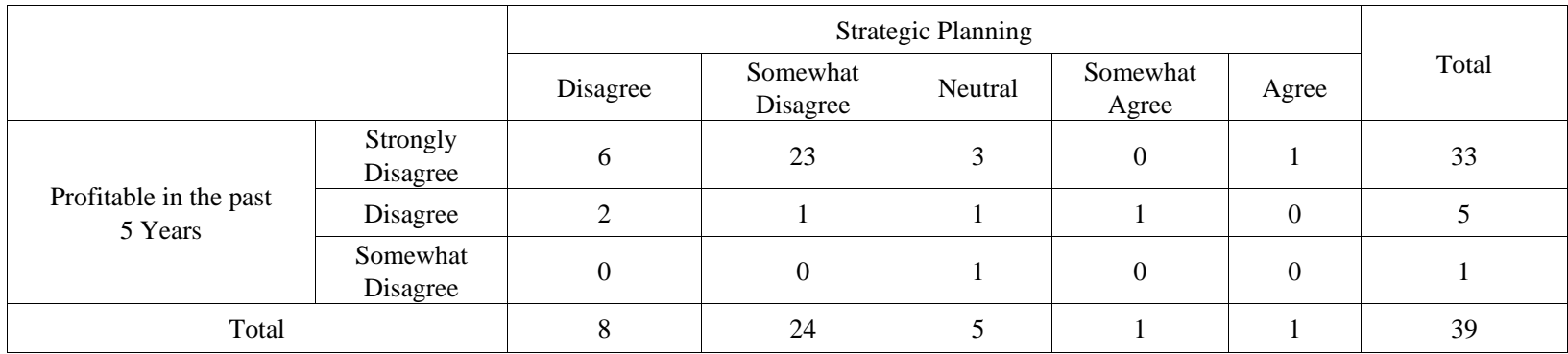

Table 5 above shows the cross-tabulation of profitable in the past 5 Years and Strategic Planning for public entities approach Cross tabulation. 
Table 6. Chi-Square test of Association of Firm Profitability in the last five years with Strategic Planning

\begin{tabular}{|c|c|c|c|}
\hline & Value & df & Asymp. Sig. (2-sided) \\
\hline Pearson Chi-Square & $17.062^{\mathrm{a}}$ & 8 & .029 \\
\hline Likelihood Ratio & 12.080 & 8 & .148 \\
\hline $\begin{array}{c}\text { Linear-by-Linear } \\
\text { Association }\end{array}$ & 1.322 & 1 & .250 \\
\hline N of Valid Cases & 39 & & \\
\hline
\end{tabular}

Table 6 shows a Chi-square the test for association between respondents' the Company's profitable in the past 5 Years versus strategic planning, at 95\% confidence interval, (chi-square $=17.062, \mathrm{p}=.029)$ revealed that the level of significance is less than 0.05 .

Decision: Reject $\mathrm{H}_{3}$ concludes that there are hindrances in implementing sound corporate governance PECGA best practices on the SOE's operational performance.

This result is supported by [50], [13] as well as [30]. [33], [60] as well as [12]) concur that Zimbabwe's enforcement system demonstrate that the country is unsuccessful in making compulsory CG compliance in its public entities effectively.

\section{Conclusions}

The results show that the level of education and job title in the SOE are related and execution of sound corporate governance PECGA best practices and the SOE's operational performance related. The results also confirmed that there were hindrances in implementing sound corporate governance PECGA best practices on the SOE's operational performance. Hence, we concluded that currently in Zimbabwe, it is not feasible to fully implement the PECGA best practices in SEPs to enhance performance. Hence the Zimbabwean's Public Corporate Governance Act must be moved from the "apply or explain" model (which implies that it relies on the disclosures requirement principles as a method of promoting the adoption of definite corporate governance practices devoid of mandating real practices) to "comply or else" model of corporate governance to achieve sustainable corporate governance success in the near future.

\section{Implication}

Based on this study's result, by implication, conflict of interest caused by separation ownership and control in agency theory should be eliminated by the board members leading by example to instil confidence into an employee to enhance good performance at the Zimbabwe State-Owned Entity. Since "apply or explain" model which relies on the disclosures requirement principles without mandating actual practices does not enhance good performance, Zimbabwe's PECGA should consider moving to "comply or else" model of corporate governance and introduce more punitive measures such as 10 to 20-year jail terms for corporate crime offenders and blacklisting of perpetrators from practising in both public and private sector in Zimbabwe.

\section{Limitations and Study Forward}

The study was undertaken at only one SOE, but others in Zimbabwe are affected by the PECGA hence giving company-specific results. Some issues arose in this study which could have been further clarified or elaborated if some of the strategic respondents had been interviewed on a face to face as questionnaires might have limited their responses. The country is currently experiencing economic challenges that might have to affect the Public Entities Corporate Governance Act's full publicity, hence affecting its full adoption in the process. The researcher recommends that further studies be conducted on a national level to have a broader view of feasibility challenges affecting the implementation of corporate governance best practices system, to go an extra mile to establish the authenticity of these findings. A market-wide study on the subject matter may yield results that may ensure that corporate adherence would create growth opportunities through new investors. This country study may reveal unearth other corporate challenges to discover with this research.

\section{Acknowledgments}

All researchers and non-researchers that contributed to this paper are highly appreciated.

\section{Conflict of Interest}

There is no conflicting of interest on this study as any source does not fund it.

\section{REFERENCES}

[1] R. B. Adams, H. Mehran. Bank board structure and performance: Evidence for large bank holding companies, Journal of Financial Intermediation, Vol. 21, pp. 243-267, 2012. DOI: 10.1016/j.jfi.2011.09.002

[2] F.F. Adegbie, E.T. Fofah. Ethics Corporate Governance and Financial Reporting in the Nigerian Banking Industry: Global Role of International Financial Reporting Standards, Accounting and Finance Research, Vol. 5, No 1, pp. 50-63, 2016.

[3] R. V. Aguilera, K. Desender, M, K. Bednar, J. Lee. Connecting the dots, bringing external corporate governance into the corporate governance puzzle, The Academy of Management Annals, Vol. 9, pp. 483-573, 2015. DOI: 


\section{$10.1080 / 19416520.2015 .1024503$}

[4] J. O. Alabede. Effect of board diversity on corporate governance structure and operating performance: evidence from the UK listed firms, Asian Journal of Accounting and Governance, Vol. 10, No 2, pp. 1-31, 2016.

[5] A. Arora, C. Sharma. Corporate governance and firm performance in developing countries: evidence from India, Corporate Governance, Vol. 16, No. 2, pp. 420-436, 2016. DOI: http://dx.doi.org/10.17576/AJAG-2016-07-06

[6] T. Babawale. Nigeria, in the crisis of governance and development. Retrospective and prospective analyses of selected issues and events: Vol. 1, The Political Economy of Development, Governance, and Globalization. Lagos: Concept Publications, 2007.

[7] S. Baškarada. Qualitative case study guidelines. The Qualitative Report, Vol. 19, No. 40, pp. 1-18, 2014 Retrieved from https://nsuworks.nova.edu/tqr/vol19/iss40/3

[8] J. Berk. The term structure of interest rates: a survey of the theories and empirical evidence. Managerial Finance, Vol. 8, No. 2, pp. 22-31, 2009.

[9] S. Bonney. Strategies to Improve the Financial Performance of State-Owned Enterprises in Ghana (Doctoral dissertation) Walden University, Minnesota, United States, 2015.

[10] A. Bryman. Mixing methods: quantitative and qualitative research: further reflections on their integration, 2017. DOI: https://doi.org/10.4324/9781315248813

[11] A. Cadbury. Report on the committee on the financial aspects of corporate governance, London: Gee. 1992.

[12] M.D. Chavunduka, Sikwila, S.N. Corporate governance in Zimbabwe: The Zimcode and state-owned enterprises connection, International Journal of Economics, Commerce and Management, Vol. 3, No. 11, pp. 651-661, 2015.

[13] P. Chimbari. Public sector corporate governance in Zimbabwe: The nexus between the ZIMCODE and state-owned enterprises, International Journal of Economics, Commerce and Management, Vol. 5, No. 7, pp. 212-221, 2017.

[14] V. Chipunza. When Ethical Leaders Speak, People, Listen, Rethinking the African Dilemmam, 2015. The Financial Gazette of 25 August 2016

[15] W. Creswell. Research Design 4th ed., London, UK: Sage Publications, 2013.

[16] Companies Act [Chapter 24:03]1951 of Zimbabwe

[17] Corporate Governance Framework for State Enterprises and Parastatals, Ministry of state enterprises and parastatals, 2010.

[18] P. R. Crow, J.C. Lockhart. How boards influence business performance: developing an explanation. Leadership \& Organization Development Journal, Vol. 37, No. 8, pp. 1022-1037, 2016. DOI: https://doi.org/10.1108/LODJ-08-20 14-0168

[19] European Central Bank. Annual Report: 2004, ECB, Frankfurt, Glossary, 2004.

[20] D.E. Gberevbie, A.I. Oyeyemi, N.O.E. Oluye. The challenges of good governance accountability of governmental agencies and development in Nigeria, Acta Universitatis Danubius, Administration, Vol. 6, No. 2, 2014.

[21] A. Ghulam, K. Binish, R. Zeeshan, A. Alia. Theoretical Perspectives of Corporate Governance. Bulletin for Business and Economics, Vol. 3, No.4, pp. 166-175, 2015.

[22] A. Ikotun. Ethics in the Nigerian Public Service: An Analytical Perspective. Lagos: Nugalitho Productions, 2004.

[23] J. W. Isingoma, J. Aduda, G. Wainaina, C.I. Mwangi. Corporate governance, firm characteristics, external environment and performance of financial institutions in Uganda: A review of literature, Cogent Business \& Management, Vol. 3, pp. 1-14, 2016. DOI: http://dx.doi.org/10.1080/23311975.2016.1261526

[24] F. J. Iturriaga, I.M. Rodríguez. Boards of directors and firm performance: The effect of multiple directorships, Spanish Journal of Finance and Accounting, Vol. 43, pp. 1-16, 2014. DOI: https://doi.org/10.1080/02102412.2014.913

[25] M. C. Jensen, W. H. Meckling. Theory of the Firm: Managerial Behaviour, Agency Costs, and Ownership Structure, Journal of Financial Economics, 3(4), pp. 305-350, 1976.

[26] K. H. Ladeur. Public Governance in the Age of Globalization, Routledge. London, 2017.

[27] J.D. Mahadeo, V.O. Hanuman, T.A. Soobaroyen. Longitudinal Study of the Implementation of Corporate Governance Code in a Developing Country; The Case of Mauritius, Journal International Association for Business and Society, Vol. 55, No. 5, pp. 738-777, 2013.

[28] G. M. Maranga. The Effects of Corporate Governance on Financial Performance of Small and Medium Enterprises in Nairobi County, Kenya, Business Administration School of Business, University of Nairobi, 2014.

[29] K. Matowanyika, M. N. Sikwila, T.J. Mabvure, Z. Muranda. Financial Reporting and Corporate Governance, Corporate Governance: A Zimbabwean Perspective. Chinhoyi University of Technology Publications, Zimbabwe, pp. 132-146, 2016

[30] J.M. Mauthi. Failure of good corporate governance in state-owned corporations in Kenya: Towards a more effective parliamentary monitoring role (Master's thesis) University of Nairobi, Nairobi, Kenya, 2014.

[31] S.L. Rusvingo. Foreign direct investors shun Zimbabwe to spark a liquidity crisis in the country $(2013-2014)$. Lagos: Sciknow Publishers, 2014.

[32] R. E. Freeman. Strategic management: a stakeholder approach. Massachusetts: Pitman, 1984.

[33] A. Maune. Corporate governance in Zimbabwe: An overview of its current state, Asian Economic and Financial Review Vol. 5, No. 1, pp. 167-178, 2015. DOI: 10.18488/journal.aefr/2015.5.1/102.1.167.178.

[34] McKinsey \& Company. performed a survey in Malaysia, 2017. Retrieved May 10, 2019, from https://www.coursehero.com.

[35] N.J. Moyo. Corporate governance- a critical analysis of the effectiveness of the board of directors in public entities in 
Zimbabwe. (Doctoral dissertation) The University of South Africa, Pretoria, South Africa, 2016.

[36] M.M. Mwangi. The Effect of Corporate Governance on Financial Performance of Companies Listed at Nairobi Security Exchange, University of Nairobi Unpublished Master of Science in Finance Project, 2013.

[37]F. Ncube, L. Maunganidze. Corporate Governance and Executive Compensation in Zimbabwe State-Owned Enterprises: A Case of Institutionalized Predation, Management, Vol. 4, No.6, pp. 131-140, 2014. DOI: 10.5923/j.mm.20140406.01.

[38] Organization for Economic Cooperation \& Development, Glossary of Statistical Terms, 2007. Retrieved from https://stats.oecd.org/glossary/detail.asp?ID=6778 accessed on 4 September 2020.

[39] A.O. Otekunrin, D.G. Fagboro, T.I. Nwanji, F.F. Asamu, O. B. Ajiboye, J.A. Falaye. Performance of deposit money banks and liquidity management in Nigeria, Banks and Bank Systems, Vol. 14, No. 3, pp. 152-161, 2019. DOI: http://dx.doi.org/10.21511/bbs.14(3).2019.13.

[40] A. O. Otekunrin, F.F. Asamu, O.O. Oye, J.K. Olowookere. Current market price of share capital and profitability of selected on Nigerian stock exchange, International Journal of Civil Engineering and Technology, Vol. 10, No.1, pp. 1274-1287, 2019.

[41] A.O. Otekunrin, T.I. Nwanji, B. Egbide, S.A. Fakile, A.I. Lawal, S.A. Ajayi, A.J. Falaye, D.F. Eluyela. Financial Ratio Analysis and Market Price of Share of Selected Quoted Agriculture and Agro-allied firms in Nigeria after Adoption of International Financial Reporting Standard, The Journal of Social Sciences Research, Vol. 4 No. 12, pp. 736-744. DOI: https://doi.org/10.32861/jssr.412.736.744

[42] Public Entities Corporate Governance Act 1 [PECGA] published, Government Gazette, 2018.

[43] Public Entities Corporate Governance Bill [PECGB] published, Government Gazette, 2017.

[44] T. Donaldson, L. E. Preston. The stakeholder theory of the corporation: concepts, evidences, and implications. Academy of Management Review, Vol. 20, No. 1, pp. 65-91, 1995.

[45] M.M. Sangarwe. An assessment of the relationship between corporate governance and performance of parastatals and state enterprises in Zimbabwe (Master's thesis) University of Zimbabwe, Harare, Zimbabwe, 2014.

[46] T.E. Scruggs, M.A. Mastropieri, K.A. McDuffie. Co-Teaching in Inclusive Classrooms: A Metasynthesis of Qualitative Research, Exceptional Children, Vol. 73, No. 4, pp. 392-416, 2007. DOI: 10.1177/001440290707300401

[47] A. M. Shahzad, M.A. Rutherford, M, P. Shartman. Stakeholder-Centric Governance and Social Corporate
Social performance: A cross-national study, Corporate Social Responsibility and Environmental Management, Vol. 23, No. 2, pp. 100-112, 2016. DOI: https://doi.org/10.1002/csr.1368

[48] T. Shaji. Corporate Excellence through Corporate Governance, International Journal of Advanced Research in Computer Science and Management Studies, Vol. 3, No. 12, pp. 10-13, 2015.

[49] O. Sifile, T.B. Bhebhe. Introduction to Corporate Governance, Corporate Governance: A Zimbabwean Perspective. Chinhoyi University of Technology Publications, Zimbabwe, pp. 1-30, 2016.

[50] O. Sifile, T. Majoni, G, R. Ndoda, M. Tukuta. Corporate Governance - A Zimbabwean Perspective Chinhoyi University of Technology Publications, 2016.

[51]D. Solomon. Nepotism, Patronage and the Public Trust, Queensland Integrity Commissioner, The Zimbabwean Newspaper, 2014.

[52] South Africa King Committee. The Institute of Directors in Southern Africa (IODSA), 1994.

[53] South Africa King Committee, The Institute of Directors in Southern Africa (IODSA), 2002.

[54] South Africa King Committee. The Institute of Directors in Southern Africa (IODSA), 2010.

[55] R.J. Sternberg. Metacognition, abilities, and developing expertise: What makes an expert student? Instructional Science Vol. 26, pp. 127-140. 1998. DOI: https://doi.org/10.1023/A:1003096215103

[56] M. Subramaniam, M. Kansal, S. Babu. Governance of mandated corporate social responsibility: Evidence from Indian Government-owned firms, Journal of Business Ethics, Springer, Vol. 143, No. 3, pp. 543-563, 2017. DOI: $10.1007 / \mathrm{s} 10551-015-2804-0$

[57]TAFGN - Transformation Agenda of the Federal Government of Nigeria (2011-2012). Summary of Federal Government's Key Priority Policies, Programmes and Projects. National Planning Commission, Abuja. pp. 5-27

[58] C. J. Ueng. The analysis of corporate governance policy and corporate financial performance, Journal of Economics and Finance, Vol. 40, pp. 514-523, 2016. DOI: $10.007 / \mathrm{s} 12197-015-9316-8$

[59] W.K. Xiang. Corporate Governance Structure and Firm Performance of Malaysian Public Listed Companies, Master of Business Administration (Corporate Governance), Faculty of Accountancy and Management, Universiti Tunku Abdul Rahman, 2018. Retrieved from http://eprints.utar.edu.my/29 84/1/MBA(CG)-2018-1401283-1_(1).pdf

[60] P. Zvavahera, R.G. Ndoda. Corporate governance and ethical behaviour: The case of the Zimbabwe Broadcasting Corporation, Journal of Academic and Business Ethics, Vol. 9, pp. 1-8, 2014. 